\title{
Naphthacemycins, novel circumventors of $\beta$-lactam resistance in MRSA, produced by Streptomyces sp. KB-3346-5. II. Structure elucidation
}

\author{
Atsushi Fukumoto ${ }^{1,3}$, Yong-Pil Kim ${ }^{2,4}$, Masato Iwatsuki ${ }^{1,2}$, Tomoyasu Hirose ${ }^{1,2}$, Toshiaki Sunazuka ${ }^{1,2}$, \\ Hideaki Hanaki ${ }^{1,2}$, Satoshi Ōmura ${ }^{2}$ and Kazuro Shiomi ${ }^{1,2}$ \\ Seventeen new compounds, naphthacemycins $A_{1}-A_{11}, B_{1}-B_{4}$ and $C_{1}-C_{2}$, were isolated from a cultured broth of Streptomyces \\ sp. KB-3346-5 during screening for circumventors of $\beta$-lactam resistance in methicillin-resistant Staphylococcus aureus. Their \\ structures were elucidated by spectroscopic studies, including NMR and X-ray crystallographic analysis. The naphthacemycin A \\ series has a new skeleton displaying a 7-phenylnaphthacene-5,6,11(12H)-trione. In contrast, the quinone moiety of the A series \\ is changed to dehydroxyquinol in the $B$ series and to a semiquinone-like structure in the $C$ series. \\ The Journal of Antibiotics (2017) 70, 568-573; doi:10.1038/ja.2017.29; published online 15 March 2017
}

\begin{abstract}
INTRODUCTION
Methicillin-resistant Staphylococcus aureus (MRSA) is a major cause of untreatable and potentially fatal hospital-associated infections. Community-acquired MRSA has also become a serious public health issue. ${ }^{1}$ MRSA is resistant to $\beta$-lactam antibiotics and usually resistant to most other classes of antibiotics. There are a few antibiotics used for MRSA, for example, vancomycin, teicoplanin, arbekacin, linezolid, daptomycin and tigecycline, but microorganism strains resistant to these compounds are increasingly being reported. In the course of screening for new anti-MRSA compounds, we found cyslabdan, which enhances the activity of imipenem (a carbapenem type $\beta$-lactam antibiotic) against MRSA. ${ }^{2,3}$ Further screening for microbial metabolites that circumvent the $\beta$-lactam resistance of MRSA led us to find the naphthacemycins $A_{1}-A_{11}(1-11), B_{1}-B_{4}(12-15)$ and $C_{1}-C_{2}$ (16-17) (Scheme 1), reported as KB-3346-5 substances in the patent by our group, ${ }^{4}$ from a cultured broth of Streptomyces sp. KB-3346-5. ${ }^{5}$ Here we describe the structure elucidation of the naphthacemycins, based on NMR study and X-ray crystallographic analysis.
\end{abstract}

\section{RESULTS AND DISCUSSION}

Physicochemical properties

Naphthacemycins (1-17) were purified from a cultured broth of Streptomyces sp. KB-3346-5, isolated from a soil sample collected in Okinawa Prefecture, Japan. ${ }^{5}$ They are red powders. Compounds 2, 4-6, 8, 11 and 14-17 have one chlorine atom, while 7 and 10 have two chlorine atoms. The IR spectra showed they all have carbonyl (1600-1720 $\left.\mathrm{cm}^{-1}\right)$ and hydroxyl (3350-3440 $\left.\mathrm{cm}^{-1}\right)$ groups. UV spectra were observed at 274-280, 302-306 and 362-408 $\mathrm{nm}$ in the naphthacemycin A series (1-11), at 246-249, 287-288, 352-354 and 414-417 $\mathrm{nm}$ in the naphthacemycin B series (12-15), and 248 and $410 \mathrm{~nm}$ in the naphthacemycin C series (16-17). Naphthacemycins are soluble in chloroform, ethyl acetate and methanol and insoluble in $n$-hexane and $\mathrm{H}_{2} \mathrm{O}$.

Structure elucidation of the naphthacemycin A series

The molecular formula of naphthacemycin $\mathrm{A}_{9}(\mathbf{9})$ was established as $\mathrm{C}_{30} \mathrm{H}_{26} \mathrm{O}_{8}$ by HR-FAB-MS. ${ }^{1} \mathrm{H}$ and ${ }^{13} \mathrm{C}$ NMR spectra and HSQC analysis revealed the presence of 30 carbons, including six methyl, six $s p^{2}$ methine, one $s p^{3}$ quaternary and $17 s p^{2}$ quaternary carbons (Table 1). The long-range couplings of HMBC correlation revealed fragments I and II (Figure 1) as follows; the cross peaks from $\mathrm{H}-1$ $\left(\delta_{\mathrm{H}} 6.55\right)$ to $\mathrm{C}-2\left(\delta_{\mathrm{C}} 163.9\right), \mathrm{C}-3\left(\delta_{\mathrm{C}} 101.6\right), \mathrm{C}-4 \mathrm{a}\left(\delta_{\mathrm{C}} 110.0\right)$ and $\mathrm{C}-12 \mathrm{a}\left(\delta_{\mathrm{C}} 154.7\right)$, from $\mathrm{H}-3\left(\delta_{\mathrm{H}} 6.25\right)$ to $\mathrm{C}-1\left(\delta_{\mathrm{C}} 105.5\right), \mathrm{C}-2, \mathrm{C}-4$ $\left(\delta_{\mathrm{C}} 165.0\right)$ and $\mathrm{C}-4 \mathrm{a}$, and from $4-\mathrm{OH}\left(\delta_{\mathrm{H}} 12.86\right)$ to $\mathrm{C}-3, \mathrm{C}-4$ and $\mathrm{C}-4 \mathrm{a}$ indicated a 2,3,5-trisubstituted phenol (ring A). The cross peaks from $\mathrm{H}_{3}-13\left(\delta_{\mathrm{H}} 1.77\right)$ and $\mathrm{H}_{3}-14\left(\delta_{\mathrm{H}} 1.83\right)$ to $\mathrm{C}-11 \mathrm{a}\left(\delta_{\mathrm{C}} 155.4\right)$, $\mathrm{C}-12\left(\delta_{\mathrm{C}} 39.2\right)$ and $\mathrm{C}-12 \mathrm{a}$ indicated a dimethyl moiety being connected to $\mathrm{C}-12 \mathrm{a}$ via $\mathrm{C}-12$. This was confirmed by the coupling between $\mathrm{H}-1$ and $\mathrm{C}-12$, and thus the fragment I was established. An oxygen atom is suggested to be attached to C-2 by its chemical shift. The cross peaks from $\mathrm{H}-8\left(\delta_{\mathrm{H}} 6.99\right)$ to $\mathrm{C}-6 \mathrm{a}\left(\delta_{\mathrm{C}} 125.8\right)$, C-7 $\left(\delta_{\mathrm{C}} 140.1\right), \mathrm{C}-9\left(\delta_{\mathrm{C}} 162.6\right)$ and $\mathrm{C}-10\left(\delta_{\mathrm{C}} 109.5\right)$, from $\mathrm{H}-10$ $\left(\delta_{\mathrm{H}} \quad 7.52\right)$ to C-6a, C-8 ( $\left.\delta_{\mathrm{C}} 124.6\right), \mathrm{C}-9, \mathrm{C}-10 \mathrm{a} \quad\left(\delta_{\mathrm{C}} 135.8\right)$ and $\mathrm{C}-11\left(\delta_{\mathrm{C}} 185.7\right)$, and from $9-\mathrm{OCH}_{3}\left(\delta_{\mathrm{H}} 3.94\right)$ to $\mathrm{C}-9$ indicated a 3,4,5-trisubstituted anisole (ring D). The cross peaks from $\mathrm{H}-17$ $\left(\delta_{\mathrm{H}} 6.39\right)$ to $\mathrm{C}-15\left(\delta_{\mathrm{C}} 120.9\right), \mathrm{C}-16\left(\delta_{\mathrm{C}} 156.7\right), \mathrm{C}-18\left(\delta_{\mathrm{C}} 159.9\right)$ and

${ }^{1}$ Graduate School of Infection Control Sciences, Kitasato University, Tokyo, Japan and ${ }^{2}$ Kitasato Institute for Life Sciences, Kitasato University, Tokyo, Japan

${ }^{3}$ Current address: Faculty of Pharmaceutical Sciences, Toho University, Funabashi, Chiba, Japan.

${ }^{4}$ Current address: Faculty of Pharmacy, Iwaki Meisei University, Iwaki, Fukushima, Japan.

Correspondence: Professor S Ōmura or Professor K Shiomi, Kitasato Institute for Life Sciences, Kitasato University, 5-9-1 Shirokane, Minato-ku, Tokyo 108-8641, Japan.

E-mail: omuras@insti.kitasato-u.ac.jp or shiomi@lisci.kitasato-u.ac.jp

Received 24 October 2016; revised 23 January 2017; accepted 1 February 2017; published online 15 March 2017 


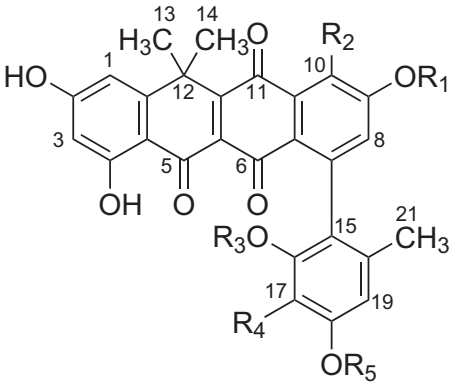

Naphthacemycin A series $(1-11)$

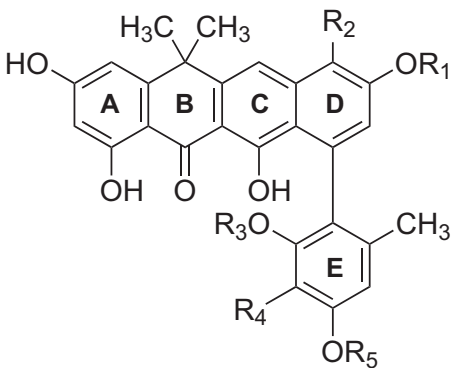

Naphthacemycin B series $(12-15)$

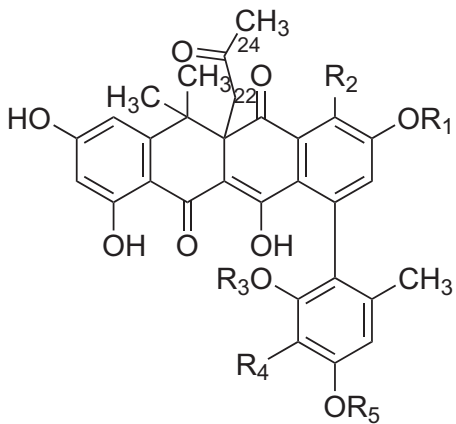

Naphthacemycin $\mathrm{C}$ series (16 and 17)

$\begin{array}{lccccc}\text { Naphthacemycin } \mathrm{A}_{1}(\mathbf{1}) & \mathrm{H} & \mathrm{H} & \mathrm{CH}_{3} & \mathrm{H} & \mathrm{H} \\ \text { Naphthacemycin } \mathrm{A}_{2}(\mathbf{2}) & \mathrm{H} & \mathrm{H} & \mathrm{CH}_{3} & \mathrm{Cl} & \mathrm{H} \\ \text { Naphthacemycin } \mathrm{A}_{3}(\mathbf{3}) & \mathrm{CH}_{3} & \mathrm{H} & \mathrm{CH}_{3} & \mathrm{H} & \mathrm{H} \\ \text { Naphthacemycin } \mathrm{A}_{4}(\mathbf{4}) & \mathrm{CH}_{3} & \mathrm{Cl} & \mathrm{CH}_{3} & \mathrm{H} & \mathrm{H} \\ \text { Naphthacemycin } \mathrm{A}_{5}(\mathbf{5}) & \mathrm{H} & \mathrm{H} & \mathrm{CH}_{3} & \mathrm{Cl} & \mathrm{CH}_{3} \\ \text { Naphthacemycin } \mathrm{A}_{6}(\mathbf{6}) & \mathrm{CH}_{3} & \mathrm{H} & \mathrm{CH}_{3} & \mathrm{Cl} & \mathrm{H} \\ \text { Naphthacemycin } \mathrm{A}_{7}(\mathbf{7}) & \mathrm{CH}_{3} & \mathrm{Cl} & \mathrm{CH}_{3} & \mathrm{Cl} & \mathrm{H} \\ \text { Naphthacemycin } \mathrm{A}_{8}(\mathbf{8}) & \mathrm{CH}_{3} & \mathrm{Cl} & \mathrm{CH}_{3} & \mathrm{H} & \mathrm{CH}_{3} \\ \text { Naphthacemycin } \mathrm{A}_{9}(9) & \mathrm{CH}_{3} & \mathrm{H} & \mathrm{CH}_{3} & \mathrm{H} & \mathrm{CH}_{3} \\ \text { Naphthacemycin } \mathrm{A}_{10}(10) & \mathrm{CH}_{3} & \mathrm{Cl} & \mathrm{CH}_{3} & \mathrm{Cl} & \mathrm{CH}_{3} \\ \text { Naphthacemycin } \mathrm{A}_{11}(11) & \mathrm{CH}_{3} & \mathrm{H} & \mathrm{CH}_{3} & \mathrm{Cl} & \mathrm{CH}_{3} \\ \text { Naphthacemycin } \mathrm{B}_{1}(\mathbf{1 2}) & \mathrm{H} & \mathrm{H} & \mathrm{H}_{2} & \mathrm{H} & \mathrm{H} \\ \text { Naphthacemycin } \mathrm{B}_{2}(\mathbf{1 3}) & \mathrm{H} & \mathrm{H} & \mathrm{CH}_{3} & \mathrm{H} & \mathrm{H} \\ \text { Naphthacemycin } \mathrm{B}_{3}(\mathbf{1 4}) & \mathrm{H} & \mathrm{H} & \mathrm{CH}_{3} & \mathrm{Cl} & \mathrm{H} \\ \text { Naphthacemycin } \mathrm{B}_{4}(\mathbf{1 5}) & \mathrm{H} & \mathrm{Cl} & \mathrm{CH}_{3} & \mathrm{H} & \mathrm{H} \\ \text { Naphthacemycin } \mathrm{C}_{1}(16) & \mathrm{CH}_{3} & \mathrm{Cl} & \mathrm{CH}_{3} & \mathrm{H} & \mathrm{H} \\ \text { Naphthacemycin } \mathrm{C}_{2}(17) & \mathrm{CH}_{3} & \mathrm{H} & \mathrm{CH}_{3} & \mathrm{Cl} & \mathrm{CH}_{3}\end{array}$

Scheme 1 Structures of naphthacemycins $A_{1}-A_{11}$ (1-11), $B_{1}-B_{4}$ (12-15) and $C_{1}-C_{2}$ (16-17).

C-19 $\left(\delta_{\mathrm{C}} 106.9\right)$, from $\mathrm{H}-19\left(\delta_{\mathrm{H}} 6.44\right)$ to $\mathrm{C}-15, \mathrm{C}-17\left(\delta_{\mathrm{C}} 96.4\right)$ and C-18, from $\mathrm{H}_{3}-21\left(\delta_{\mathrm{H}} 2.06\right)$ to $\mathrm{C}-15, \mathrm{C}-19$ and $\mathrm{C}-20\left(\delta_{\mathrm{C}} 137.0\right)$, from $16-\mathrm{OCH}_{3}\left(\delta_{\mathrm{H}} 3.65\right)$ to $\mathrm{C}-16$, and from $18-\mathrm{OCH}_{3}\left(\delta_{\mathrm{H}} 3.80\right)$ to $\mathrm{C}-18$ indicated a 2-monosubstituted 3,5-dimethoxytoluene (ring E). The coupling between $\mathrm{H}-8$ and $\mathrm{C}-15$ suggested a connection of rings $\mathrm{D}$ and $\mathrm{E}$ at $\mathrm{C}-7$ and $\mathrm{C}-15$, respectively, and thus the fragment II was established. Among the remaining three carbons, C-5 $\left(\delta_{C} 185.0\right)$ had couplings with $\mathrm{H}-1$ and $\mathrm{H}-3$ and $\mathrm{C}-6\left(\delta_{\mathrm{C}}\right.$ 182.6) had a coupling with $\mathrm{H}-10$. They are considered to be ${ }^{4} \mathrm{~J}_{\mathrm{CH}} \mathrm{W}$-couplings, and C-5 and C-6 are suggested to bond to C-4a and C-6a, respectively (Figure 2). The chemical shifts of C- $6\left(\delta_{C}\right.$ 182.6) and C-11 $\left(\delta_{C}\right.$ 185.7) indicated that they form a quinone. If the remaining $\mathrm{C}-5 \mathrm{a}\left(\delta_{\mathrm{C}} 135.5\right)$ bonds to C-5 and C-11a to form ring B, and C-5a-C-6 and C-11-C-11a bondings form ring $\mathrm{C}$, the naphthacenequinone structure is constructed. C-2 is suggested to be hydroxylated by the molecular formula. The carbon connections unrevealed by HMBC were clarified by INADEQUATE analysis (Table 1). Thus the structure of 9 was elucidated as shown in Scheme 1. It has a 7-phenylnaphthacene-5,6,11 $(12 \mathrm{H})$-trione skeleton. Most structurally related compounds, tetarimycin $\mathrm{A}^{6}$ and fasamycins ${ }^{7}$, were recently reported by Brady and co-workers as antibacterial agents. The structure was confirmed by $\mathrm{X}$-ray crystallographic analysis as shown in Figure 3. The naphthacenequinone forms a planar skeleton.
The molecular formula of naphthacemycin $\mathrm{A}_{8}(\mathbf{8})$ was established as $\mathrm{C}_{30} \mathrm{H}_{25} \mathrm{ClO}_{8}$ by HR-FAB-MS, and this suggested that 8 was chlorinated analog of $9 .{ }^{1} \mathrm{H}$ and ${ }^{13} \mathrm{C}$ NMR spectra of 8 were similar to those of 9, except for ring $\mathrm{D}$ (Table 1). The $\mathrm{HMBC}$ correlations from $\mathrm{H}-8\left(\delta_{\mathrm{H}} 6.93\right)$ to $\mathrm{C}-6 \mathrm{a}\left(\delta_{\mathrm{C}} 127.1\right), \mathrm{C}-7\left(\delta_{\mathrm{C}} 137.4\right), \mathrm{C}-9\left(\delta_{\mathrm{C}} 158.4\right)$ and $\mathrm{C}-10\left(\delta_{\mathrm{C}} 120.4\right)$ and from $9-\mathrm{OCH}_{3}\left(\delta_{\mathrm{H}} 3.95\right)$ to C-9 were observed, and C-10 was a quaternary carbon (Figure 4). Thus, the structure of 8 was elucidated as 10-chloro-9, which was confirmed by X-ray crystallographic analysis (Figure 5). In contrast to $\mathbf{9}$, the naphthacenequinone of $\mathbf{8}$ bent about $40^{\circ}$ at two quinone carbonyl atoms of ring $\mathrm{C}$.

The structures of the other naphthacemycin A series were elucidated by comparison with NMR data of $\mathbf{8}$ or $\mathbf{9}$ or other A series compounds (Supplementary Tables S1 and S2) and analyses of HMBC correlations (Supplementary Figure S1).

\section{Structure elucidation of the naphthacemycin B series}

The molecular formula of naphthacemycin $\mathrm{B}_{1}$ (12) was established as $\mathrm{C}_{27} \mathrm{H}_{22} \mathrm{O}_{7}$ by HR-FAB-MS, which indicated 12 was 28 mass units (CO) less than $1 .{ }^{1} \mathrm{H}$ and ${ }^{13} \mathrm{C}$ NMR spectra and HSQC analysis revealed the presence of 27 carbons, including three methyl, seven $s p^{2}$ methine, one $s p^{3}$ quaternary and sixteen $s p^{2}$ quaternary carbons (Table 1). The structure was elucidated by long-range couplings of $\mathrm{HMBC}$ correlation (Figure 4$)$. The cross peaks from $\mathrm{H}-1\left(\delta_{\mathrm{H}} 6.65\right)$ to 
Table 1 NMR spectroscopic data for $8,9,12$ and $17^{a}$

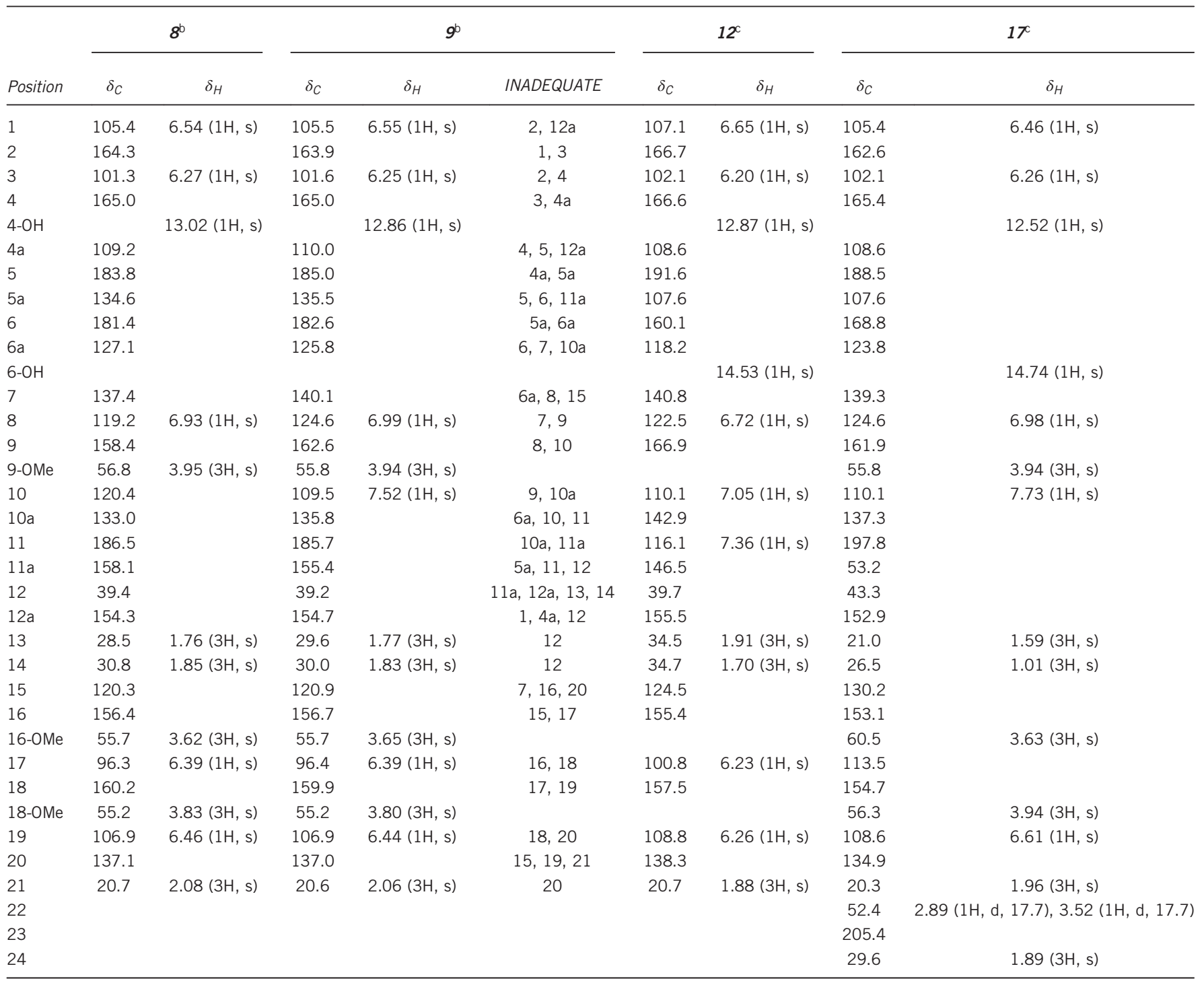

a300 $\mathrm{MHz}$ for ${ }^{1} \mathrm{H}$ NMR and $75 \mathrm{MHz}$ for ${ }^{13} \mathrm{C}$ NMR.

bolvent: $\mathrm{CDCl}_{3}$.

cSolvent: acetone- $\mathrm{d}_{6}$. $\delta_{\mathrm{H}}($ Int, mult, J in $\mathrm{Hz})$.

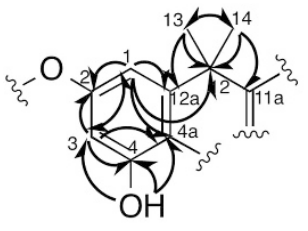

fragment I

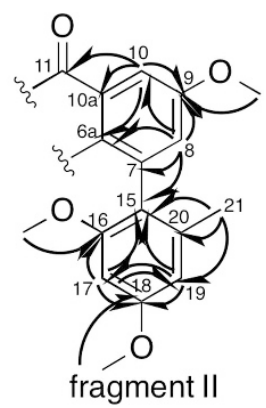

Figure 1 Partial structures of $\mathbf{9}$.

C-2 $\left(\delta_{C} 166.7\right), C-3\left(\delta_{C} 102.1\right)$ and $C-4 a\left(\delta_{C} 108.6\right)$, from $\mathrm{H}-3$ $\left(\delta_{\mathrm{H}} 6.20\right)$ to $\mathrm{C}-1\left(\delta_{\mathrm{C}} 107.1\right), \mathrm{C}-2, \mathrm{C}-4\left(\delta_{\mathrm{C}} 166.6\right)$ and $\mathrm{C}-4 \mathrm{a}$, and from $4-\mathrm{OH}\left(\delta_{\mathrm{H}} 12.87\right)$ to $\mathrm{C}-3, \mathrm{C}-4$ and $\mathrm{C}-4 \mathrm{a}$ indicated a 2,3,5-trisubstituted phenol (ring A). The cross peaks from $\mathrm{H}_{3}-13\left(\delta_{\mathrm{H}} 1.91\right)$ and $\mathrm{H}_{3}-14$ $\left(\delta_{\mathrm{H}} 1.70\right)$ to $\mathrm{C}-11 \mathrm{a}\left(\delta_{\mathrm{C}} 146.5\right), \mathrm{C}-12\left(\delta_{\mathrm{C}} 39.7\right)$ and $\mathrm{C}-12 \mathrm{a}\left(\delta_{\mathrm{C}} 155.5\right)$ indicated a dimethyl moiety connected to $\mathrm{C}-12 \mathrm{a}$ via $\mathrm{C}-12$. This was confirmed by the coupling between $\mathrm{H}-1$ and $\mathrm{C}-12$. The cross peaks from $\mathrm{H}-8\left(\delta_{\mathrm{H}} 6.72\right)$ to $\mathrm{C}-6 \mathrm{a}\left(\delta_{\mathrm{C}} 118.2\right), \mathrm{C}-9\left(\delta_{\mathrm{C}} 166.9\right)$ and $\mathrm{C}-10\left(\delta_{\mathrm{C}}\right.$ 110.1) and from $\mathrm{H}-10\left(\delta_{\mathrm{H}} 7.05\right)$ to C-6a, C-8 $\left(\delta_{\mathrm{C}} 122.5\right), \mathrm{C}-9, \mathrm{C}-10 \mathrm{a}\left(\delta_{\mathrm{C}} 142.9\right)$ and $\mathrm{C}-11\left(\delta_{\mathrm{C}} 116.1\right)$ indicated a 3,4,5-trisubstituted phenol (ring D). The cross peaks from $\mathrm{H}-11$ $\left(\delta_{\mathrm{H}}\right.$ 7.36) to $\mathrm{C}-5 \mathrm{a}\left(\delta_{\mathrm{C}} 107.6\right), \mathrm{C}-6 \mathrm{a}$ and $\mathrm{C}-12$ and from $6-\mathrm{OH}$ $\left(\delta_{\mathrm{H}} 14.53\right)$ to $\mathrm{C}-5 \mathrm{a}, \mathrm{C}-6\left(\delta_{\mathrm{C}} 160.1\right)$ and C-6a indicated a $2,3,5,6-$ tetrasubstituted phenol (ring $\mathrm{C}$ ), which condensed with ring $\mathrm{D}$ and connected to ring A via C-12. Comparing NMR data and structures of 12 with 1 , it is appropriate to form 4,4-dimethylcyclohexadienone (ring B) by C-4a, 5, 5a, 11a, 12 and 12a, though C-5 had no coupling with neighboring protons. The resemblance of the NMR data also suggested that a hydroxyl residue is attached to C-2 of $\mathbf{1 2}$ as in $\mathbf{1}$. The cross peaks from $\mathrm{H}-17\left(\delta_{\mathrm{H}} 6.23\right)$ to $\mathrm{C}-15\left(\delta_{\mathrm{C}} 124.5\right), \mathrm{C}-16\left(\delta_{\mathrm{C}} 155.4\right)$, $\mathrm{C}-18\left(\delta_{\mathrm{C}} 157.5\right)$ and $\mathrm{C}-19\left(\delta_{\mathrm{C}} 108.8\right)$, from $\mathrm{H}-19\left(\delta_{\mathrm{H}} 6.26\right)$ to $\mathrm{C}-15, \mathrm{C}-17\left(\delta_{\mathrm{C}} 100.8\right)$ and $\mathrm{C}-18$, and from $\mathrm{H}_{3}-21\left(\delta_{\mathrm{H}} 1.88\right)$ to C-15, C-19 and C-20 ( $\delta_{C}$ 138.3) indicated 2-monosubstituted 


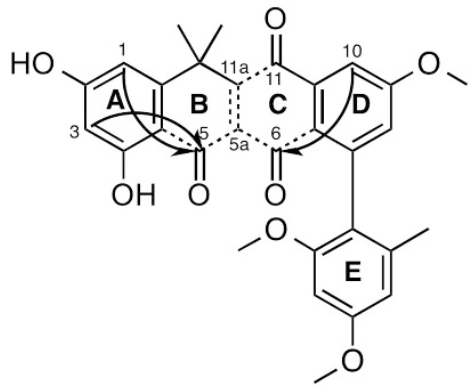

Figure 2 Structure elucidation of $\mathbf{9}$.

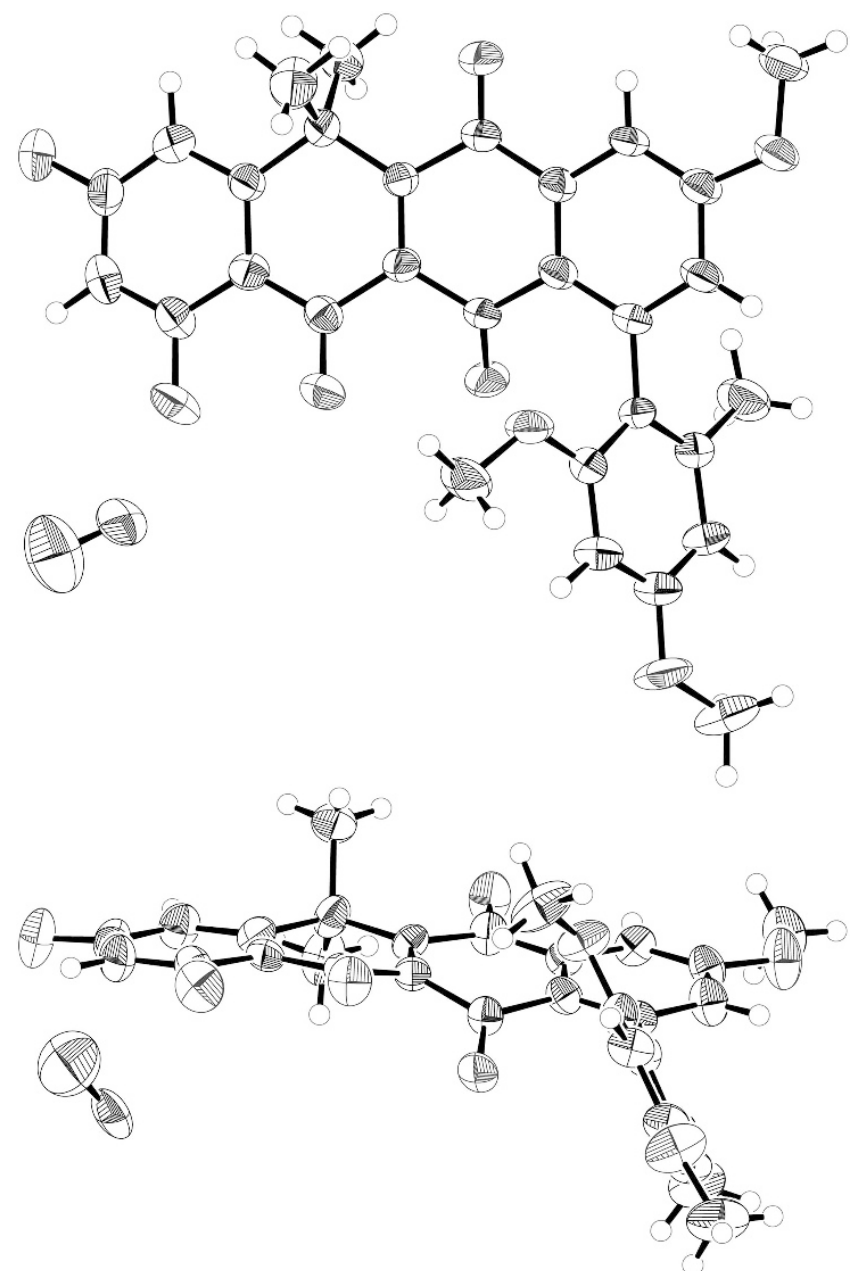

Figure 3 ORTEP (Oak Ridge thermal ellipsoid plot) plot of the X-ray crystallographic structure of $\mathbf{9}$.

3,5-dihydroxytoluene (ring E). The coupling between H-8 and C-15 indicated that ring $\mathrm{E}$ connects to ring $\mathrm{D}$ at $\mathrm{C}-7$. Thus, the structure of 12 was elucidated as 6,11-didehydro- $O^{16}$-demethyl-6,11-dideoxo11-hydroxy-1.

Structure elucidation of the naphthacemycin C series The molecular formula of naphthacemycin $\mathrm{C}_{2}$ (17) was established as $\mathrm{C}_{33} \mathrm{H}_{31} \mathrm{ClO}_{9}$ by $\mathrm{HR}-\mathrm{FAB}-\mathrm{MS}$, which indicated 17 was 58 mass units $\left(\mathrm{C}_{3} \mathrm{H}_{6} \mathrm{O}\right)$ more than $11 .{ }^{1} \mathrm{H}$ and ${ }^{13} \mathrm{C}$ NMR spectra and HSQC analysis revealed the presence of 33 carbons, including seven methyl, one

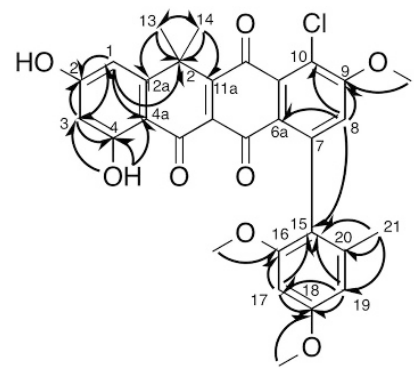

8

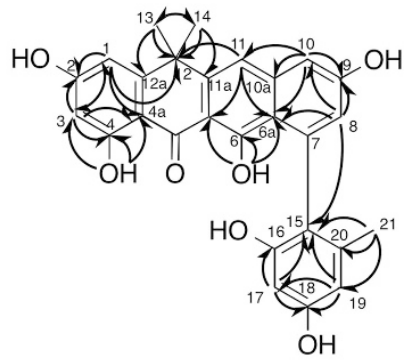

12
Figure 4 Structure elucidation of 8 and 12 by HMBC.

$s p^{3}$ methylene, five $s p^{2}$ methine, two $s p^{3}$ quaternary and eighteen $s p^{2}$ quaternary carbons (Table 1). The structure was elucidated by long-range couplings of $\mathrm{HMBC}$ correlation (Figure 6). The cross peaks from $\mathrm{H}-1\left(\delta_{\mathrm{H}} 6.46\right)$ to $\mathrm{C}-2\left(\delta_{\mathrm{C}} 162.6\right), \mathrm{C}-3\left(\delta_{\mathrm{C}} 102.1\right)$ and $\mathrm{C}-4 \mathrm{a}$ $\left(\delta_{\mathrm{C}} 108.6\right)$, from H-3 $\left(\delta_{\mathrm{H}} 6.26\right)$ to $\mathrm{C}-1\left(\delta_{\mathrm{C}} 105.4\right), \mathrm{C}-2, \mathrm{C}-4\left(\delta_{\mathrm{C}} 165.4\right)$ and $\mathrm{C}-4 \mathrm{a}$, and from $4-\mathrm{OH}\left(\delta_{\mathrm{H}} 12.52\right)$ to $\mathrm{C}-3, \mathrm{C}-4$ and $\mathrm{C}-4 \mathrm{a}$ indicated a 2,3,5-trisubstituted phenol (ring $A$ ). The cross peaks from $\mathrm{H}_{3}-13$ $\left(\delta_{\mathrm{H}} 1.59\right)$ and $\mathrm{H}_{3}-14\left(\delta_{\mathrm{H}} 1.01\right)$ to $\mathrm{C}-11 \mathrm{a}\left(\delta_{\mathrm{C}} 53.2\right), \mathrm{C}-12\left(\delta_{\mathrm{C}} 43.3\right)$ and $\mathrm{C}-12 \mathrm{a}\left(\delta_{\mathrm{C}} 152.9\right)$ indicated a dimethyl moiety was connected to C-12a via $\mathrm{C}-12$. This was confirmed by the coupling between $\mathrm{H}-1$ and $\mathrm{C}-12$. The cross peaks from $\mathrm{H}-8\left(\delta_{\mathrm{H}} 6.98\right)$ to $\mathrm{C}-6 \mathrm{a}\left(\delta_{\mathrm{C}} 123.8\right), \mathrm{C}-9\left(\delta_{\mathrm{C}} 161.9\right)$ and $\mathrm{C}-10\left(\delta_{\mathrm{C}} 110.1\right), \mathrm{H}-10\left(\delta_{\mathrm{H}} 7.73\right)$ to $\mathrm{C}-6 \mathrm{a}, \mathrm{C}-8\left(\delta_{\mathrm{C}} 124.6\right), \mathrm{C}-9$, $\mathrm{C}-10 \mathrm{a}\left(\delta_{\mathrm{C}} 137.3\right)$ and $\mathrm{C}-11\left(\delta_{\mathrm{C}} 197.8\right)$, and from $9-\mathrm{OCH}_{3}\left(\delta_{\mathrm{H}} 3.94\right)$ to C-9 indicated a 3,4,5-trisubstituted anisole (ring D). The cross peaks from $6-\mathrm{OH}\left(\delta_{\mathrm{H}} 14.74\right)$ to $\mathrm{C}-5 \mathrm{a}\left(\delta_{\mathrm{C}} 107.6\right), \mathrm{C}-6\left(\delta_{\mathrm{C}} 168.8\right)$ and C-6a and from $\mathrm{H}_{2}-22\left(\delta_{\mathrm{H}} 2.89,3.52\right)$ to $\mathrm{C}-5 \mathrm{a}, \mathrm{C}-11$ and $\mathrm{C}-11 \mathrm{a}$ indicated a 2,3,5,6-tetrasubstituted 4-hydroxy-2,4-cyclohexadienone (ring C), condensed with ring $\mathrm{D}$ and connected to ring $\mathrm{A}$ via $\mathrm{C}-12$. The cross peaks from $\mathrm{H}_{3}-24\left(\delta_{\mathrm{H}} 1.89\right)$ to $\mathrm{C}-22\left(\delta_{\mathrm{C}} 52.4\right)$ and $\mathrm{C}-23\left(\delta_{\mathrm{C}} 205.4\right)$ and from $\mathrm{H}_{2}-22$ to $\mathrm{C}-23$ indicated that a 2-oxopropyl residue was attached to C-11a. Comparing NMR data and structures of $\mathbf{1 7}$ with 11, it is appropriate to form 4,4-dimethyl-2-cyclohexenone (ring B) by C-4a, 5, 5a, 11a, 12 and 12a, though C-5 had no coupling with neighboring protons. The chemical shifts of ring $\mathrm{E}$ of 17 is quite similar to 11, which suggests ring $\mathrm{E}$ of $\mathbf{1 7}$ is 2-monosubstituted 4-chloro-3,5-dimethoxytoluene. This was confirmed by the cross peaks from $\mathrm{H}-19\left(\delta_{\mathrm{H}} \quad 6.61\right)$ to $\mathrm{C}-15\left(\delta_{\mathrm{C}} 130.2\right)$, C-17 $\left(\delta_{\mathrm{C}} 113.5\right)$ and $\mathrm{C}-18\left(\delta_{\mathrm{C}} 154.7\right)$, from $\mathrm{H}_{3}-21\left(\delta_{\mathrm{H}} 1.96\right)$ to $\mathrm{C}-15$, $\mathrm{C}-19\left(\delta_{\mathrm{C}} 108.6\right)$ and $\mathrm{C}-20\left(\delta_{\mathrm{C}} 134.9\right)$, from $16-\mathrm{OCH}_{3}\left(\delta_{\mathrm{H}} 3.63\right)$ to $\mathrm{C}-16\left(\delta_{\mathrm{C}} 153.1\right)$, and from $18-\mathrm{OCH}_{3}\left(\delta_{\mathrm{H}} 3.94\right)$ to $\mathrm{C}-18$. The coupling between $\mathrm{H}-8$ and $\mathrm{C}-15$ indicated that ring $\mathrm{E}$ connects to ring $\mathrm{D}$ at $\mathrm{C}-7$. Thus, C-11a of 11 was substituted with a 2-oxopropyl group and the C-6 ketone was reduced in 17.

The molecular formula of naphthacemycin $\mathrm{C}_{1}(\mathbf{1 6})$ was established as $\mathrm{C}_{32} \mathrm{H}_{29} \mathrm{ClO}_{9}$ by $\mathrm{HR}-\mathrm{FAB}-\mathrm{MS}$, which indicated 16 was 14 mass units $\left(\mathrm{CH}_{2}\right)$ less than $17 .{ }^{1} \mathrm{H}$ and ${ }^{13} \mathrm{C}$ NMR spectra of 16 were quite similar to those of 17, except for rings D and E (Supplementary Table S3). The $\mathrm{H}-10$ signal of $\mathbf{1 7}$ disappeared in $\mathbf{1 6}$ and the cross peaks of $\mathrm{HMBC}$ from $\mathrm{H}-8\left(\delta_{\mathrm{H}} 7.01\right)$ to $\mathrm{C}-6 \mathrm{a}\left(\delta_{\mathrm{C}} 126.7\right), \mathrm{C}-9\left(\delta_{\mathrm{C}} 158.6\right)$ and $\mathrm{C}-10$ $\left(\delta_{\mathrm{C}} 120.8\right)$ and from $9-\mathrm{OCH}_{3}\left(\delta_{\mathrm{H}} 4.03\right)$ to $\mathrm{C}-9$ were observed, which indicated that a chlorine was attached to the $\mathrm{C}-10$ of ring $\mathrm{D}$ (Figure 6). The $18-\mathrm{OCH}_{3}$ signal of 17 was also absent in $\mathbf{1 6}$ and an $\mathrm{H}-17$ $\left(\delta_{\mathrm{H}} 6.37\right)$ signal appeared in 17. The cross peaks from $\mathrm{H}-17\left(\delta_{\mathrm{H}} 6.37\right)$ to $\mathrm{C}-15\left(\delta_{\mathrm{C}} 123.7\right), \mathrm{C}-16\left(\delta_{\mathrm{C}} 158.1\right), \mathrm{C}-18\left(\delta_{\mathrm{C}} 158.4\right)$ and $\mathrm{C}-19$ $\left(\delta_{\mathrm{C}} 109.4\right)$, from $\mathrm{H}-19\left(\delta_{\mathrm{H}} 6.39\right)$ to $\mathrm{C}-15, \mathrm{C}-17\left(\delta_{\mathrm{C}} 97.4\right)$ and $\mathrm{C}-18$, from $\mathrm{H}_{3}-21\left(\delta_{\mathrm{H}} 2.01\right)$ to $\mathrm{C}-15, \mathrm{C}-19$ and $\mathrm{C}-20\left(\delta_{\mathrm{C}} 137.0\right)$, and from $16-\mathrm{OCH}_{3}\left(\delta_{\mathrm{H}} 3.64\right)$ to $\mathrm{C}-16$ indicated a ring $\mathrm{E}$ structure of 2-monosubstituted 3,5-dimethoxytoluene. Thus 16 was 10- 


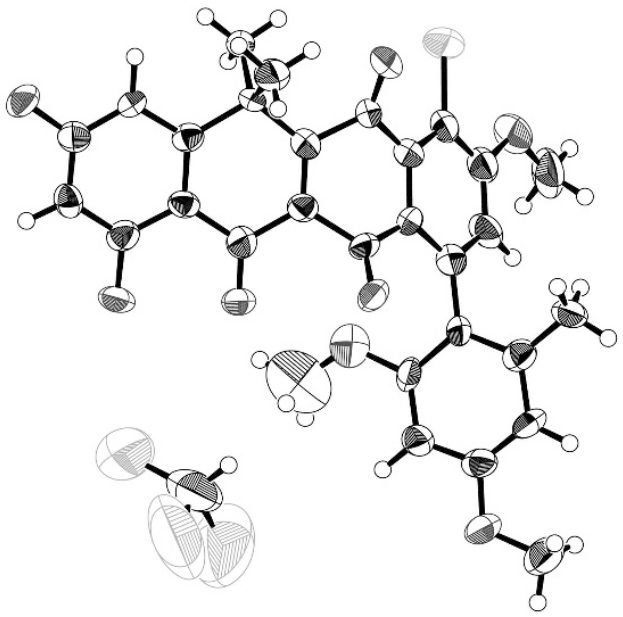

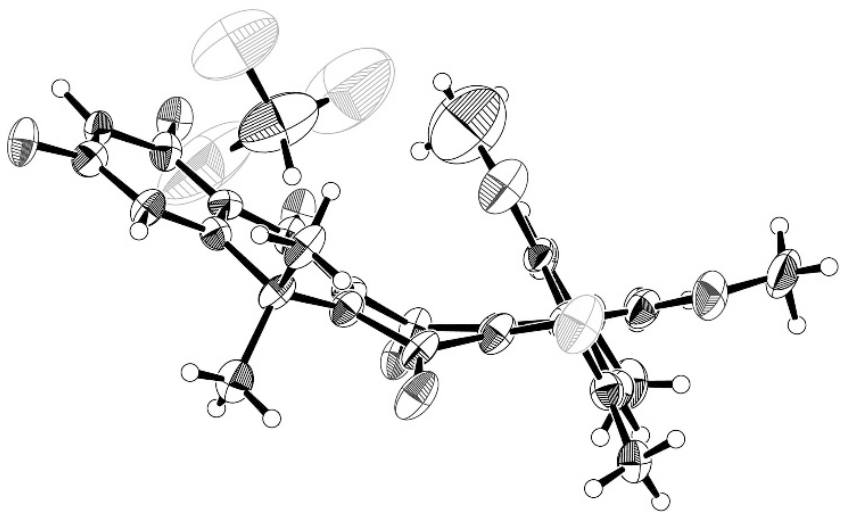

Figure 5 ORTEP plot of the X-ray crystallographic structure of $\mathbf{8}$.

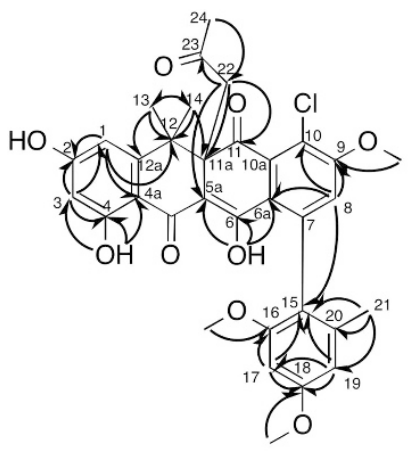

16

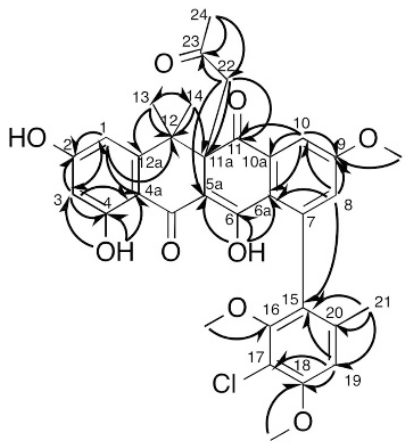

17
Figure 6 Structure elucidation of 16 and 17 by HMBC.

chloro-17-dechloro- $\mathrm{O}^{18}$-demethyl-17. We have not elucidated the configurations of 16 and 17 yet.

\section{Circumvention of $\beta$-lactam resistance in MRSA}

The circumvention of $\beta$-lactam resistance in MRSA was measured by enhancement of imipenem activity on MRSA using the paper disk method. Naphthacemycins alone showed no antibacterial activity against a clinically isolated MRSA strain K24 at $0.01-1 \mu \mathrm{g}$ per disk. When the agar plates contained $10 \mu \mathrm{g} \mathrm{ml}^{-1}$ of imipenem, which also did not affect the growth of MRSA, 0.01-1 $\mu$ g per disks of naphthacemycins showed
Table 2 Enhancement of imipenem anti-MRSA activity by naphthacemycins

\begin{tabular}{|c|c|c|c|c|c|}
\hline \multirow[b]{2}{*}{ Compound } & \multicolumn{5}{|c|}{$\begin{array}{c}\text { Inhibition zone diameter (mm) by } 6 \mathrm{~mm} \text { paper disk } \\
\text { Agar plate containing imipenem }\left(10 \mu \mathrm{g} \mathrm{ml^{-1 }}\right) \\
\text { Amount of compound ( } \mu \mathrm{g} \text { per disk) }\end{array}$} \\
\hline & 0.01 & 0.03 & 0.1 & 0.3 & 1 \\
\hline 1 & - & - & - & 10 & 16 \\
\hline 2 & - & 10 & 16 & 17 & 22 \\
\hline 3 & 9 & 14 & 18 & 19 & 21 \\
\hline 4 & - & 10 & 11 & 13 & 19 \\
\hline 5 & 9 & 15 & 17 & 21 & 25 \\
\hline 6 & 11 & 15 & 19 & 21 & 23 \\
\hline 7 & 10 & 11 & 14 & 19 & 21 \\
\hline 8 & 9 & 12 & 13 & 15 & 16 \\
\hline 9 & 7 & 13 & 15 & 17 & 17 \\
\hline 10 & 11 & 12 & 12 & 14 & 15 \\
\hline 11 & - & 10 & 11 & 16 & 16 \\
\hline 12 & - & - & - & 10 & 14 \\
\hline 13 & - & 8 & 11 & 15 & 17 \\
\hline 14 & - & 13 & 14 & 14 & 16 \\
\hline 15 & - & 9 & 10 & 15 & 18 \\
\hline 16 & - & 9 & 11 & 15 & 17 \\
\hline 17 & - & - & 7 & 10 & 17 \\
\hline
\end{tabular}

inhibition zones (Table 2). Compounds $\mathbf{3}$ and $\mathbf{5 - 1 0}$ inhibited the growth of MRSA at $0.01 \mu \mathrm{g}$ per disk in the presence of imipenem. Among them, 6 and 10 showed the largest inhibition zones $(11 \mathrm{~mm})$ at $0.01 \mu \mathrm{g}$ per disk. The detailed activity of naphthacemycins against MRSA will be reported in an accompanying paper. ${ }^{5}$

\section{CONCLUSION}

In conclusion, 17 new compounds designated naphthacemycins were isolated from the culture broth of Streptomyces sp. KB-3346-5. They are circumventors of $\beta$-lactam resistance and enhanced imipenem activity against $\beta$-lactam resistant MRSA. Naphthacemycins are 1-phenylnaphthacene antibiotics produced by Streptomyces sp. Many naphthacene type compounds have been isolated from actinomycetes, but most of them have partially unsaturated rings, such as tetracyclines and anthracyclines. Some highly unsaturated naphthacene compounds have been reported to be produced by actinomycetes, such as tetracenomycin D, galtamycin and tetracenoquinocin. ${ }^{8-10} \mathrm{~A}$ biosynthetic intermediate of tetracycline, pretetramid and an aglycone of anthracycline, $\eta$-pyrromycinone, are classified in the latter. ${ }^{11,12}$ Naphthacemycins A and $\mathrm{B}$ series also belong to the latter group, but they are the first compounds having a 1-phenylnaphthacene skeleton isolated from a natural origin.

\section{METHODS}

General experimental procedure

${ }^{1} \mathrm{H}$ NMR $(300 \mathrm{MHz})$ and ${ }^{13} \mathrm{C}$ NMR $(75 \mathrm{MHz})$ spectra were recorded on a Varian XL-300 spectrometer. Chemical shifts are shown in $\delta$ values (p.p.m.) relative to the solvents (acetone- $\mathrm{d}_{6}$ at 2.05 p.p.m. for ${ }^{1} \mathrm{H}$ NMR and at 29.8 p.p. m. for ${ }^{13} \mathrm{C} \mathrm{NMR}$; $\mathrm{CDCl}_{3}$ at 7.26 p.p.m. for ${ }^{1} \mathrm{H} \mathrm{NMR}$ and at 77.0 p.p.m. for ${ }^{13} \mathrm{C}$ NMR; DMSO- $\mathrm{d}_{6}$ at 2.50 p.p.m. for ${ }^{1} \mathrm{H}$ NMR and at 39.5 p.p.m. for ${ }^{13} \mathrm{C}$ NMR). INADEQUATE experiment of $\mathbf{9}(170 \mathrm{mg})$ was carried out for $100 \mathrm{~h}$ by $125 \mathrm{MHz}$ NMR using methanol- $\mathrm{d}_{4}$ as a solvent. Mass spectrometry was conducted on a JEOL JMS-AX505 HA spectrometer. The UV and IR spectra were measured with a Hitachi U-2810 spectrophotometer and a Horiba FT-710 Fourier transform infrared spectrometer, respectively. Optical rotations were recorded on a JASCO model DIP-1000 polarimeter. 


\section{Assay of antibacterial activity}

Measurement of inhibition zone of naphthacemycins, with or without imipenem, to evaluate circumvention activity of $\beta$-lactam resistance were carried out by paper disk method, as reported previously. ${ }^{3}$

\section{Data availability}

The X-ray crystallographic data have been deposited at the Cambridge Crystallographic Data Centre (CCDC) under deposition numbers CCDC 1536220 (8) and CCDC 1536223 (9).

\section{CONFLICT OF INTEREST}

The authors declare no conflict of interest.

\section{ACKNOWLEDGEMENTS}

This work was supported in part by a grant of the twenty-first century COE Program, Ministry of Education, Culture, Sports, Science and Technology, Japan. We are grateful to Ms Akiko Nakagawa and Ms Noriko Sato of the School of Pharmacy, Kitasato University, for measurements of mass and NMR spectra. We thank Varian Technologies Japan Ltd for the measurement of INADEQUATE.

1 Diep, B. A. \& Otto, M. The role of virulence determinants in community-associated MRSA pathogenesis. Trends Microbiol. 16, 361-369 (2008)
2 Fukumoto, A. et al. Cyslabdan, a new potentiator of imipenem activity against methicillin-resistant Staphylococcus aureus, produced by Streptomyces sp. K04-0144. I. Taxonomy, fermentation, isolation and structural elucidation. J. Antibiot. 61, 1-6 (2008).

3 Fukumoto, A. et al. Cyslabdan, a new potentiator of imipenem activity against methicillinresistant Staphylococcus aureus, produced by Streptomyces sp. K04-0144. II. Biological activities. J. Antibiot. 61, 7-10 (2008).

4 Ōmura, S. et al. (Kitasato Institute, Japan; Kyowa Hakko Kirin Co., Ltd., Japan). KB-3346-5 substances, their fermentative manufacture, and antibacterial agents containing them. Jpn Kokai Tokkyo Koho, JP2009046404A (2009).

5 Fukumoto, A. et al. Naphthacemycins, novel circumventors of $\beta$-lactam resistance in MRSA, produced by Streptomyces sp. KB-3346-5. I. The taxonomy of the producing strain, and the fermentation, isolation and antibacterial activities. J. Antibiot (doi:10.1038/ja.2017.28).

6 Feng, Z., Kallifidas, D. \& Brady, S. F. Functional analysis of environmental DNA-derived type II polyketide synthases reveals structurally diverse secondary metabolites. Proc. Natl Acad. USA 108, 12629-12634 (2011).

7 Feng, Z., Chakraborty, D., Dewell, S. B., Reddy, B. V. B. \& Brady, S. F. Environmental DNA-encoded antibiotics fasamycins A and B inhibit FabF in type II fatty acid biosynthesis. J. Am. Chem. Soc. 134, 2981-2987 (2012).

8 Yue, S., Motamedi, H., Wendt-Pienkowski, E. \& Hutchinson, C. R. Antracycline metabolites of tetracenomycin C-ninproducing Streptomyces glaucescens mutants. J. Bacteriol. 167, 581-586 (1986).

9 Egorov, L. V., Tetent'eva, T. G., Rudneva, N. A., Egorenko, G. G. \& Ivantiskaia, L. P. Experimental study of the antitumor anthracycline antibiotic aclarubicin (aclacinomycin A). Antibiot. Med. Biotekhnol. 30, 918-927 (1985).

10 Motohashi, K., Takagi, M. \& Shin-ya, K. Tetracenoquinocin and 5-iminoaranciamycin from a sponge-derived Streptomyces sp. Sp080513GE-26. J. Nat. Prod. 73 755-758 (2010).

11 Zhang, W., Watanabe, K., Wang, C. C. \& Tang, Y. Investigation of early tailoring reactions in the oxytetracycline biosynthetic pathway. J. Biol. Chem. 282, 25717-25725 (2007)

12 Brockmann, H., Pla, L. C. \& Lenk, W. ל-pyrromycinone. Angew. Chem. 69, 477 (1957).

Supplementary Information accompanies the paper on The Journal of Antibiotics website (http://www.nature.com/ja) 